\title{
Susceptibility of Foodborne Pathogens Isolated from Fresh-Cut Products and Organic Vegetable to Organic Acids and Sanitizers
}

\author{
Kyung Min Park, Minwoo Baek, Hyun Jung Kim, Byeong Sam Kim, and Minseon Koo* \\ Korea Food Research Institute, Gyeonggi 463-746, Korea \\ (Received January 10, 2013/Revised May 28, 2013/Accepted July 31, 2013)
}

\begin{abstract}
In this study, we evaluated the ability of various disinfectants to suppress the growth of microorganisms in fresh-cut products and organic vegetable. The growth of more than $50 \%$ of $B$. cereus isolates were suppressed by $50 \%$ ethanol, $0.1 \%$ hydrogen peroxide, $0.4 \%$ sodium hypochlorite or $1 \%$ calcium oxide. E. coli generally showed high susceptibility to concentration of $10 \%$ ethanol, $0.4 \%$ sodium hypochlorite and $1 \%$ calcium oxide. Eighty percent or more of $S$. aureus isolates exhibited resistance to ethanol, hydrogen peroxide and sodium hypochlorite, but the isolates were susceptible to concentrations of $1 \%$ calcium oxide. All isolates evaluated in this study were sensitive to benzalkonium chloride (BAC) and growth in the presence of $2.0 \mu \mathrm{g} / \mathrm{mL}$ of BAC was completely inhibited. These pathogens showed widely different susceptibilities to different organic acids. Greater than $0.5 \%$ acetic acid and $2 \%$ and higher concentrations of malic acid and tartaric acid inhibited the growth of $60 \%$ of the isolates of $B$. cereus. Two percent acetic acid and tartaric acid inhibited $50 \%$ of the $S$. aureus isolates. Seventy percent of the E. coli isolates were resistant to malic acid and susceptible to $1 \%$ acetic acid and $10 \%$ tartaric acid. The antibacterial effects of the various sanitizers evaluated in this study were not only dependent on the type of disinfectant but also on the pathogen. Thus, it is important to select a sanitizer that is safe and effective at removing specific types of microorganisms.
\end{abstract}

Key words: Fresh cut produce, Organic vegetable, Antimicrobial agent, Foodborne pathogen

\section{Introduction}

Dietary consumption of vegetables and fruits has health benefit, and prevent or reduce the risk of some chronic disease. The benefits associated with fresh cut products have contributed to a substantial increase in the consumption of ready-to-eat vegetables. However, these changes in dietary habits, including the consumption of raw or minimally processed fruits and vegetables, have been accompanied by a number of foodborne illnesses attributed to fresh food ${ }^{1)}$. This increase in consumption has thus been correlated with an increased frequency of outbreaks of illness associated with raw fruits and vegetables ${ }^{2,3}$.

Escherichia coli, Staphylococcus aureus, Salmonella spp., and Bacillus cereus are major pathogens that found from raw vegetables in worldwide ${ }^{4)}$. Thus, it is essential to use effective sanitizers against pathogenic microorganisms to minimize the risk of foodborne illness associated with fresh vegetables and fruits.

Ethanol, hydrogen peroxide $\left(\mathrm{H}_{2} \mathrm{O}_{2}\right)$, and sodium hypo-

\footnotetext{
*Correspondence to: Minseon Koo, Korea Food Research Institute, Gyeonggi 463-746, Korea

Tel: 82-31-780-9161, Fax: 82-31-709-9876

E-mail: minsk@kfri.re.kr
}

chlorite $(\mathrm{NaClO})$, which are sanitizers that can be use directly or indirectly on food, are the most widely used and studied sanitizers in Korea. However, chemical disinfectants can produce chemical residues on the surface of fruits and vegetables and was known potentially carcinogenic or mutagenic-products, such as haloacetic acid, that can be harmful to human health ${ }^{5}$. Therefore, there is a need for safer and more effective antimicrobial treatments in order to inactive microorganism of fruits and vegetables.

Recently, many natural organic acids have been studied as alternatives to chemical disinfectants. Organic produce must be cultivated with no agricultural chemicals agents, thus, organic acids are suitable for controlling microorganisms on organic produce. Because organic acids are "Generally Recognized As Safe" (GRAS) for treatment of food ingredients ${ }^{6}$. Various organic acids have been used to control microorganisms, and they are generally recognized as being effective and safe household sanitizers ${ }^{7}$. The antimicrobial activity of organic acids, including lactic, citric and acetic acids for searching alternative sanitizing method have evaluated against pathogens in much studies ${ }^{7,12)}$.

Washing is a critical step in fresh cut produce processing to inhibit the growth of microorganism and maintenance food quality. But prolonged and repeated exposed to a chemical disinfectant to remove microorganism may development 
resistance to the disinfectant itself against pathogens. Generally, a establishment of resistance to L.monocytogenes and $S$. aureus by frequent use of Benzalkonium chloride in food-processing is well known ${ }^{11)}$.

Many chemical sanitizers, such as hydrogen peroxide ${ }^{8)}$, sodium hypochlorite ${ }^{9)}$, calcium oxide ${ }^{10)}$, and benzalkonium chloride $^{11)}$, have already been investigated for efficacy against pathogens. However most previous studies has focused on the inhibitory effects of sanitizers on food deliberately inoculated with foodborne pathogens, while few studies have tested about effectiveness of disinfectants on microorganisms isolated from food itself.

Therefore, the present study performed to evaluate the susceptibility of foodborne pathogens, including B. cereus, $S$. aureus, and E. coli isolated from fresh product to various sanitizing agents. The objectives of this work were to compare the effectiveness of an organic acid against food pathogen isolate and recommend the appropriate use of sanitizers against the contaminating pathogen.

\section{Materials and Methods}

\section{Source of foodborne pathogens}

B. cereus (65 isolates), S. aureus (5 isolates), and E. coli (9 isolates) isolates in 96 fresh and organic vegetables were used $^{13)}$. All cultures maintained on tryptic soy agar (Merck, Darmstadt, Germany) slants at $4^{\circ} \mathrm{C}$. Four standard cultures (Escherichia coli ATCC 10536, Salmonella typhimurium, ATCC 13311, Bacillus cereus ATCC 21772, and Staphylococcus aureus ATCC 33591) were used as control strains.

\section{Antimicrobial agents}

The chemical sanitizers, ethanol, sodium hypochlorite, calcium oxide and benzalkonium chloride, purchased from Sigma Chemical Co. (St. Louis, MO, USA). The organic acids included acetic acid, citric acid, fumaric acid, malic acid, lactic acid, tartaric acid, and pyruvic acid and purchased from Merck (Damstadt, Germany). All antimicrobial agents except calcium oxide diluted with sterile distilled water and filtered using a $0.2 \mu \mathrm{m}$ membrane filter (Sartorius AG, Goettingen, Germany). Calcium oxide was diluted with dimethyl sulfoxide (Sigma).

\section{Antimicrobial susceptibility test}

\section{Strain activation}

Before the experiment, all strains in this study activated in tryptic soy broth (TSB, Merck, Darmstadt, Germany) and incubated for $24 \mathrm{~h}$ either $30^{\circ} \mathrm{C} \mathrm{B}$. cereus or $37^{\circ} \mathrm{C} \mathrm{S}$. aureus and $E$. coli. The activated culture reactivated in a fresh TSB. The final cell concentration of $10^{6} \sim 10^{7} \mathrm{CFU} / \mathrm{mL}$ used in this study determined using a turbidity of $0.5 \mathrm{McF}$ arland $(\mathrm{McF})$ in a Densichek (bioMérieux, Marcy I'Etoile, France).

\section{Broth dilution method}

Antimicrobial agents diluted in sterile water and added to the TSB at final concentrations of $10 \%, 30 \%$, and $50 \%$ ethanol; $0.1 \%, 0.5 \%$, and $1 \%$ hydrogen peroxide; $0.1 \%$, $0.2 \%$, and $0.4 \%$ sodium hypochlorite; and $1 \%, 3 \%$, and $5 \%$ calcium oxide. Organic acids were tested at concentrations of $0.5 \%, 1 \%, 2 \%, 5 \%$, and $10 \%$. Antimicrobial susceptibility effect was determined by the broth dilution method as recommended by the CLSI ${ }^{14)}$. A change in turbidity of the cultures was observed by measuring the absorbance using a Microplate reader (BioTek Instrument, Winoski, USA) at $600 \mathrm{~nm}$. All experiments were performed in triplication for each isolate. And viability of bacteria was confirmed by plating on tryptic soy agar (TSA, Merck, Darmstadt, Germany).

The following calculation was used: inhibition rate $(\%)=$ $100 \times($ the number of strains with inhibited growth/the number of tested strains.)

\section{Disk diffusion method}

The antibacterial activity of benzalkonium chloride against isolates of E. coli, $S$. aureus, and B. cereus determined using the disc diffusion method by the CLSI. Inoculums of $10^{5}$ $10^{6} \mathrm{CFU} / \mathrm{mL}$ were spread on the surface of Muller-Hinton agar (Hanil Komed, Gyeonggi-do, Korea). Sterile paper discs (6 mm diameter, Toyo Roshi Kaisha Ltd., Tokyo, Japan) were separately laid to the surface of the inoculated agar plates after being dropped the disinfectant solutions of different concentrations.

These plates were incubated for $24 \mathrm{~h}$ at either $37^{\circ} \mathrm{C} \mathrm{S}$. aureus and E. coli or $30^{\circ} \mathrm{C} \mathrm{B}$. cereus. After incubation, the diameter of the inhibition zones around the discs was measured a sensitivity of $0.05 \mathrm{~mm}$.

\section{Statistical analysis}

The significance level $p<0.05$ between the mean values was verified in the manner of an ANOVA test by a statistical analysis system (SAS Institute Inc., North Carolina, USA) program for statistical analysis of data.

\section{Results}

\section{Effects of ethanol, hydrogen peroxide, sodium hypo- chlorite and calcium oxide}

Table 1 show the inhibition efficacy of B. cereus, E. coli and $S$. aureus isolates by ethanol, hydrogen peroxide, sodium hypochlorite and calcium oxide.

Ten percent ethanol inhibited the growth of $43 \%$ of $B$. cereus and $66 \%$ of E. coli isolates, and $30 \%$ ethanol had 
Table 1. Bactericidal effects of ethanol, hydrogen peroxide, sodium hypochlorite and calcium oxide against pathogens isolated from fresh-cut produce and organic vegetables by the broth dilution method

\begin{tabular}{|c|c|c|c|c|}
\hline Treatment & Concentration (\%) & B. cereus $(n=65)$ & E. $\operatorname{coli}(n=9)$ & S. aureus $(n=5)$ \\
\hline \multirow{3}{*}{ ethanol } & 10 & $43.1 \pm 1.54^{1)^{f 2}}$ & $66.7 \pm 0.00^{c}$ & $20 \pm 0.00^{\mathrm{g}}$ \\
\hline & 30 & $47.7 \pm 1.54^{\mathrm{e}}$ & $77.8 \pm 0.00^{\mathrm{b}}$ & $20 \pm 0.00^{\mathrm{g}}$ \\
\hline & 50 & $56.2 \pm 2.31^{\mathrm{d}}$ & $83.3 \pm 5.56^{\mathrm{a}}$ & $20 \pm 0.00^{\mathrm{g}}$ \\
\hline \multirow{3}{*}{ hydrogen peroxide } & 0.1 & $59.2 \pm 0.77^{1) \mathrm{b} 2)}$ & $44.4 \pm 0.00^{\mathrm{d}}$ & $20 \pm 0.00^{\mathrm{e}}$ \\
\hline & 0.5 & $61.5 \pm 0.00^{\mathrm{b}}$ & $50.0 \pm 5.58^{c}$ & $20 \pm 0.00^{\mathrm{e}}$ \\
\hline & 1 & $66.2 \pm 1.54^{\mathrm{a}}$ & $50.0 \pm 5.58^{\mathrm{c}}$ & $20 \pm 0.00^{\mathrm{e}}$ \\
\hline \multirow{3}{*}{ sodium hypochlorite } & $0.1(100 \mathrm{ppm})$ & $2.3 \pm 0.77^{1 \mathrm{le} 2)}$ & $0.0 \pm 0.00^{\mathrm{f}}$ & $0.0 \pm 0.00^{\mathrm{f}}$ \\
\hline & $0.2(200 \mathrm{ppm})$ & $29.2 \pm 1.54^{\mathrm{c}}$ & $0.0 \pm 0.00^{\mathrm{f}}$ & $20.0 \pm 0.00^{\mathrm{d}}$ \\
\hline & $0.4(400 \mathrm{ppm})$ & $75.4 \pm 0.00^{\mathrm{b}}$ & $100.0 \pm 0.00^{\mathrm{a}}$ & $20.0 \pm 0.00^{\mathrm{d}}$ \\
\hline \multirow{3}{*}{ calcium oxide } & 1 & $97.7 \pm 0.77^{1 \mathrm{ab} 2)}$ & $94.4 \pm 5.56^{\mathrm{ab}}$ & $80.0 \pm 0.00^{c}$ \\
\hline & 3 & $99.2 \pm 0.77^{\mathrm{ab}}$ & $100 \pm 0.00^{\mathrm{a}}$ & $90.0 \pm 0.00^{\mathrm{b}}$ \\
\hline & 5 & $100 \pm 0.00^{\mathrm{a}}$ & $100 \pm 0.00^{\mathrm{a}}$ & $90.0 \pm 0.00^{\mathrm{b}}$ \\
\hline
\end{tabular}

${ }^{1)}$ Percentage of positive samples based on inhibiting the growth of pathogens isolated from tested sample.

${ }^{2)}$ Mean values with different superscripts are significantly different at $p<0.05$.

inhibitory efficacy against $47 \%$ of $B$. cereus and $77 \%$ of $E$. coli isolates. The $50 \%$ solution of ethanol was the most effective disinfectant for the $E$. coli isolates. The inhibition rate of $S$. aureus isolates was not change by the ethanol concentration.

The inhibition effects of microorganisms with hydrogen peroxide $\left(\mathrm{H}_{2} \mathrm{O}_{2}\right)$ were between $44 \%$ and $66 \%$. $0.1 \% \mathrm{H}_{2} \mathrm{O}_{2}$ inhibited approximately $66 \%$ of $B$. cereus isolates. Meanwhile, $0.1 \%, 0.5 \%$ and $1 \% \mathrm{H}_{2} \mathrm{O}_{2}$ significantly inhibited $E$. coli by up to $50 \%$ and inhibited $S$. aureus by less than $20 \%$.

At concentrations of 400 ppm sodium hypochlorite $(\mathrm{NaOCl})$ presented strong antimicrobial activity against $E$. coli and $B$. cereus. $\mathrm{NaOCl}$ inhibited $B$. cereus by $75 \%$ and suppressed the growth of $E$. coli by $100 \%$, but it did not inhibit $S$. aureus strains by more than $20 \%$.

Calcium oxide showed better disinfecting efficiency than ethanol, hydrogen peroxide and sodium hypochlorite. A solution of $1 \%$ calcium oxide eliminated up to $80 \%$ of the tested pathogens. Three percent calcium oxide inhibited $B$. cereus, E. coli and S. aureus by $99 \%, 100 \%$ and $90 \%$, respectively. Five percent calcium oxide caused $100 \%$ growth inhibition of the $B$. cereus isolates.

\section{Effects of benzalkonium chloride}

The bactericidal of benzalkonium chloride evaluated by the disc diffusion method, and the results are shown in Table 2. The susceptibility of benzalkonium chloride found to be microorganism-dependent in this study.

Additionally, based on the diameters of the inhibition zones for the three microorganisms, benzalkonium chloride exhibit the best antimicrobial activity on $B$. cereus, followed by $E$. coli and $S$. aureus. At a concentration of $0.1 \mu \mathrm{g} / \mathrm{mL}, 98.8 \%$ of $B$. cereus isolates and $88.9 \%$ of $E$. coli isolates were
Table 2. Antimicrobial effects of benzalkonium chloride ( $0.1 \mathrm{ug} /$ $\mathrm{mL}$ ) against pathogens isolated from fresh-cut produce and organic vegetables by the disc ${ }^{1)}$ diffusion method

\begin{tabular}{cccc}
\hline \multirow{2}{*}{\begin{tabular}{c} 
Zone diameter $(\mathrm{mm})$ \\
\cline { 2 - 4 }
\end{tabular}} & B. cereus $(\mathrm{n}=65)$ & E. coli $(\mathrm{n}=9)$ & $\begin{array}{c}\text { S. aureus } \\
(\mathrm{n}=5)\end{array}$ \\
\hline$>7$ & $1(1.5)^{2)}$ & $1(11.1)$ & 0 \\
$7-9$ & $14(21.5)$ & $5(55.6)$ & 0 \\
$10-12$ & $29(44.6)$ & $3(33.3)$ & $2(40.0)$ \\
$13-15$ & $13(20.0)$ & 0 & $1(20.0)$ \\
$16-18$ & $4(6.2)$ & 0 & $2(40.0)$ \\
$19-21$ & $4(6.2)$ & 0 & 0 \\
\hline
\end{tabular}

${ }^{1)}$ Disc diameter $=6 \mathrm{~mm}$

${ }^{2)}$ Number and percent of positive samples

sensitive to BAC. Meanwhile, all $S$. aureus isolates were inhibited by $0.1 \mu \mathrm{g} / \mathrm{mL}$ of BAC.

\section{Effects of acidic disinfectants}

In this study, acetic acid, malic acid and tartaric acid were selected in a preliminary bactericidal test using standard cultures of $S$. aureus ATCC 33591, B. cereus ATCC 21772 and E. coli ATCC 10536.

They exhibited better antibacterial activity than fumaric acid, lactic acid, pyruvic acid and citric acid against $S$. aureus, $B$. cereus and E. coli. (data not shown). The bactericidal effects of the selected organic acids on pathogen are shown in Table 3. The bactericidal effects against isolates increased with the concentration of the organic acids. The susceptibility of $E$. coli and B. cereus to acetic acid showed better than $S$. aureus. In particular, $2 \%$ acetic acid suppressed the growth of all E. coli and $92 \%$ of B. cereus isolates, and each pathogen showed strong susceptibility relative to $S$. aureus 
Table 3. Bactericidal effects of different concentrations of organic acid against pathogen isolates in fresh-cut produce and organic vegetables

\begin{tabular}{|c|c|c|c|c|}
\hline \multirow{2}{*}{ Organic acids } & \multirow{2}{*}{ Conc. (\%) } & \multicolumn{3}{|c|}{ Inhibition rate $(\%)$} \\
\hline & & B. cereus $(n=65)$ & E. $\operatorname{coli}(\mathrm{n}=9)$ & S. aureus $(\mathrm{n}=5)$ \\
\hline \multirow{3}{*}{ Acetic acid } & 0.5 & $65.4 \pm 0.77^{1 \mathrm{~d} 2)}$ & $10.0 \pm 10.00^{g}$ & $0.0 \pm 0.00^{\mathrm{h}}$ \\
\hline & 1 & $84.6 \pm 3.08^{\mathrm{bc}}$ & $80.0 \pm 0.00^{c}$ & $33.3 \pm 11.11^{\mathrm{f}}$ \\
\hline & 2 & $92.3 \pm 1.54^{\mathrm{ab}}$ & $100.0 \pm 0.00^{\mathrm{a}}$ & $55.6 \pm 0.00^{\mathrm{e}}$ \\
\hline \multirow{3}{*}{ Malic acid } & 2 & $68.5 \pm 0.77^{b}$ & $0.0 \pm 0.00^{\mathrm{e}}$ & $55.6 \pm 0.00^{\mathrm{c}}$ \\
\hline & 5 & $77.7 \pm 0.77^{\mathrm{ab}}$ & $30.0 \pm 10.00^{\mathrm{d}}$ & $55.6 \pm 0.00^{c}$ \\
\hline & 10 & $79.2 \pm 2.31^{\mathrm{a}}$ & $30.0 \pm 10.00^{\mathrm{d}}$ & $72.2 \pm 5.56^{\mathrm{ab}}$ \\
\hline \multirow{3}{*}{ Tartaric acid } & 2 & $63.8 \pm 3.85^{\mathrm{cd}}$ & $40.0 \pm 0.00^{\mathrm{e}}$ & $55.6 \pm 0.00^{\mathrm{d}}$ \\
\hline & 5 & $79.2 \pm 2.31^{\mathrm{b}}$ & $40.0 \pm 0.00^{\mathrm{e}}$ & $61.1 \pm 5.56^{\mathrm{d}}$ \\
\hline & 10 & $87.7 \pm 0.00^{\mathrm{a}}$ & $70.0 \pm 10.00^{c}$ & $61.1 \pm 5.56^{\mathrm{d}}$ \\
\hline
\end{tabular}

${ }^{1)}$ Mean values plus and minus the standard deviation in inhibition rate (\%)

${ }^{2)}$ Mean values with different superscripts are significantly different at $p<0.05$

$(\mathrm{P}<0.05)$. In the present experiment, $0.5 \%, 1 \%$, and $2 \%$ acetic acid showed to produce up to $50 \%$ inhibition of $S$. aureus.

Malic acid had a weak inhibitory effect on $E$. coli relative to $S$. aureus and B. cereus. Solutions of only $2 \%$ malic acid suppressed the growth of up to $50 \%$ of $B$. cereus and $S$. aureus isolates. Two percent malic acid did not inhibit the growth of $E$. coli, but $5 \%$ and $10 \%$ malic acid slightly inhibited $30 \%$ of $E$. coli isolates.

The addition of tartaric acid inhibited the growth of microorganisms. Sixty-three percent of B. cereus, $40 \%$ of $E$. coli and $55 \%$ of $S$. aureus isolates were affected by the antimicrobial activity of $2 \%$ tartaric acid. Increasing the tartaric acid concentration led to a reduction in the number of $B$. cereus and E. coli isolates. However, no increase in inhibition rate was observed in $S$. aureus strains for concentrations greater than $5 \%$ tartaric acid.

\section{Discussion}

These experiments were performed to compare the susceptibility of various disinfectants on pathogen isolates from fresh-cut products and organic vegetable. All of the sanitizers were capable of inhibiting B. cereus, $S$. aureus and E. coli, but the bactericidal activity was different.

E. coli isolates presented strong inhibition effect in $10 \%$ ethanol relative to the other pathogens. Furthermore, the antibacterial effect of ethanol on E. coli and B. cereus significantly increased with increasing concentration, and $80 \%$ or more of $E$. coli isolates showed inhibition of growth in ethanol of $50 \%$. On the other hand, the bactericidal effect of ethanol against $S$. aureus was the lowest. These findings are similar to results from a study by Kim et al. ${ }^{10)}$ reported that a range of $5 \%$ to $20 \%$ ethanol did not suppress the growth of $S$. aureus. Ethanol showed a relatively poor antimicrobial effect against $S$. aureus compared with $E$. coli and B. cereus. Additionally, $60 \%$ to $70 \%$ ethanol killed gram-negative bacteria such as $E$. coli by inhibiting the cross-linkage of peptidoglycan and inducing cellular lysis. On the other hand, ethanol had weak activity against gram-positive bacteria ${ }^{15)}$. Generally, foodborne pathogens were more effectively inhibited when exposed to $50 \%$ than $20 \%$ to $40 \%$ ethanol solution $^{16)}$. However, this study found that $50 \%$ ethanol inhibited poorly $B$. cereus and $S$. aureus.

Hydrogen peroxide is an effective and well-known disinfectant that has bactericidal efficacy due to its strong oxidizing powder ${ }^{17)}$. However, hydrogen peroxide can leave a residue on the surface of fruits and vegetables and is potentially harmful to humans ${ }^{18,19)}$. In this study, $1 \% \mathrm{H}_{2} \mathrm{O}_{2}$ suppressed the growth of approximately $66 \%$ of $B$. cereus, $50 \%$ of $E$. coli and $20 \%$ of $S$. aureus isolates. Therefore, hydrogen peroxide is a better inhibitor of $B$. cereus and is less effective at inhibiting $S$. aureus relative to $B$. cereus and $E$. coli.

Sodium hypochlorite $(\mathrm{NaOCl})$ is widely used for reducing the bacterial contamination of fruits, vegetables and fresh produce ${ }^{20)}$. However, with chlorine treatment, organic agents in the washing water rapidly inactive chlorine ${ }^{21,22)}$. Therefore, pre-cleaning prior to chlorine treatment is required to chlorine compounds to be effective. In this study, $400 \mathrm{ppm} \mathrm{NaOCl}$ had the highest antibacterial effect against $E$. coli and $B$. cereus, however, showed a weak inhibitory effect of only $20 \%$ against $S$. aureus isolates.

Previous study demonstrated that low concentrations of $\mathrm{NaOCl}$ had bactericidal effects on the growth of $S$. aureus, B. cereus and $E$. coli ${ }^{9,23)}$. Lee et al. $^{23)}$ reported that the level of $S$. aureus in lettuce was reduced from $51 \mathrm{CFU} / \mathrm{mL}$ to 31 $\mathrm{CFU} / \mathrm{mL}$ after treatment with a $20-\mathrm{ppm} \mathrm{NaOCl}$ solution, and treatment with 100-ppm solutions reduced the level to $6 \mathrm{CFU} / \mathrm{mL}$. Jeong et $a l^{9)}$ reported that initial E. coli contamination levels of $39 \mathrm{CFU} / \mathrm{mL}$ in lettuce were reduced to 
$29 \mathrm{CFU} / \mathrm{mL}$ after treatment with a 50-ppm $\mathrm{NaOCl}$ solution and to $1 \mathrm{CFU} / \mathrm{mL}$ after treatment with a $100-\mathrm{ppm}$ solution. The current study reported that $100-\mathrm{ppm}$ to $200-\mathrm{ppm} \mathrm{NaOCl}$ concentrations did not show the inhibition effect against $E$. coli and $B$. cereus and $S$. aureus isolates found to be resistant to even relatively high concentrations of $\mathrm{NaOCl}$. This discrepancy might be due to differences in the experimental conditions or the properties of the test bacteria. Additionally, microorganisms isolated from commercially available food may be adapted to disinfectants after repeated exposure in the food-processing environment.

Scallop shells considered to be waste products that cause environmental problems. However, by using heat treatment, calcium carbonate, the main component of the scallop shell, is converted to calcium oxide $(\mathrm{CaO})$, which has antibacterial properties $^{24}$. In various studies, the presence of high concentrations of calcium in solution interfered with enzyme activity and thus inhibited the growth of microorganisms $\mathrm{s}^{25}$. Treatment with $1 \%$ calcium oxide killed more than $80 \%$ of three pathogen isolates in this study. In particular, $\mathrm{CaO}$ was effective for the inhibition of $S$. aureus compared to other sanitizers.

Similar results were obtained by Kim et $a l^{10)}$, who observed that $\mathrm{CaO}$ showed better disinfecting efficiency against $B$. cereus than chlorine and hydrogen peroxide. $\mathrm{CaO}$ is not commonly used as disinfectant for washing the fresh cut vegetable and fruit in food processing industry yet. Thus $\mathrm{CaO}$ might show the best antimicrobial activity against most of $B$. cereus, E. coli and $S$. aureus isolates in this study.

$\mathrm{BAC}$, an active quaternary ammonium compound (QAC), is widely used as a disinfectant in the medical and food-processing environment to eliminate and prevent the spread of unwanted microorganisms. However, the frequent use and misuse of QACs, such as the use of high concentrations of the disinfectant or insufficient rinsing and exposure times, has raised concerns regarding whether QAC-resistant bacteria from food and the food environment may emerge ${ }^{26)}$.

QAC resistance of Staphylococci in the food industry and in humans is well known. Ase et al. ${ }^{11)}$ and Heir et al. ${ }^{27)}$ reported that $10 \%$ to $13 \%$ of Staphylococci isolated from areas of the food industry and Listeria monocytogenes isolated from fish product showed resistance (MIC $\geq 3.0 \mu \mathrm{g} / \mathrm{mL}$ ) to BAC. The minimum inhibitory concentration (MIC) guideline for QACs-resistant bacteria is over $3.0 \mu \mathrm{g} / \mathrm{ml}$, and the MIC guideline for QACs-sensitive bacteria is under $2.0 \mu \mathrm{g} / \mathrm{mL}^{26)}$. All isolates used in this study were sensitive to BAC, and a concentration of $2.0 \mu \mathrm{g} / \mathrm{mL}$ was completely inhibitory. The failure to detect BAC-resistant pathogens was thought to be due to different source of the samples. Pathogen isolates in this study were isolated from fresh vegetables that had been packed by minimal processing after harvesting. Therefore, the bacteria had little chance to contact BAC, a disinfectant used in the food-processing environment, thus all of the strains could be sensitive to BAC.

This study found that BAC was more effective against $E$. coli than against $S$. aureus and B. cereus. The outer membrane surface of gram positive strains, such as $S$. aureus, reduces the penetration of sanitizers, thus, the difference in the outer membrane structure between gram positive and negative bacterial is likely the cause of reducing sensitivity by $\mathrm{BAC}^{28)}$.

Organic food was cultivated without using of agricultural chemicals and chemical sanitizers, and organic acids may use as an alternative safe sanitizer for controlling foodborne pathogens on this type of produce. This study demonstrated the antimicrobial effects of organic acids as an alternative to chemical sanitizers against pathogens isolated from organic vegetables. The bactericidal effects against pathogen isolates increased with the concentration of the organic acids. However, the susceptibility to organic acids was different depending on the type of pathogen. The susceptibility of $S$. aureus to acetic acid, malic acid and tartaric acid were better than that to chemical sanitizer such as ethanol, hydrogen peroxide and sodium hypochlorite. In particular, $2 \%$ acetic acid led to inhibition of most of $E$. coli and B. cereus strains, which is a relatively high level of antimicrobial activity relative to $S$. aureus $(\mathrm{P}<0.05)$. Similar results were found by Minor $e a^{299}$. They demonstrated that acetic acid had greater inhibitory activity on the growth of microorganism than did lactic acid, citric acid, and phosphoric acid. B. cereus and $S$. aureus isolates showed higher susceptibility to malic acid and tartaric acid than did E. coli.

According to Jo et al ${ }^{30)}$ tartaric acid completely inhibited the growth of pathogenic $E$. coli. This finding differed from the results of the present study. In this study, B. cereus was more inhibited than E. coli and $S$. aureus at a concentration of $10 \%$ tartaric acid. Taken together, the findings support the previous observations regarding the efficacy of organic acids in controlling the growth of food related pathogen $\mathrm{s}^{31,32)}$. Hsiao et al. ${ }^{33)}$ reported that $B$. cereus cultures were inhibited by concentrations of tartaric acid and citric acid greater than $10 \mathrm{~g} /$ L. In particular, they demonstrated that $B$. cereus appeared to be relatively sensitive to many organic acids, including acetic acid, citric acid, tartaric acid, and malic acid. Acidic disinfectants killed the pathogens by breaking the bonds nucleic acids and by precipitating proteins. The antimicrobial activity of organic acids, meanwhile, is attributed to a reduction of $\mathrm{pH}$ by the ionization of undissociated acid molecules. A low external $\mathrm{pH}$ can disrupt the substrate transport system by altering cell membrane permeability ${ }^{34,35)}$.

The detection rate for B. cereus (67.7\%) in this study was higher than for E. coli (9.4\%) and S. aureus (5.2\%). The common sanitizers for inactivation $B$. cereus isolates in the food industry are sodium hypochlorite ${ }^{36,37)}$ and hydrogen per- 
oxide $^{37)}$ due to sporicidal properties. The applied commercial amount is between 50 and $200 \mathrm{ppm}$ of free chlorine of $\mathrm{NaOCl}^{38)}$ and between $1-3.5 \%$ of hydrogen peroxide ${ }^{37)}$.

In this study, acetic acid $(0.5 \%)$, malic acid $(2 \%)$ and tartaric acid (2\%) showed similar inhibition effect against $B$. cereus with $1 \% \mathrm{H}_{2} \mathrm{O}_{2}$ and were more effective than $200 \mathrm{ppm}$ $\mathrm{NaOCl}$. It is suggested that washing by organic acid could be as effective as hydrogen peroxide and sodium hypochlorite.

\section{Conclusion}

When populations of microorganism are exposed to a high concentration of an antimicrobial agent, such as ethanol, hydrogen peroxide, sodium hypochlorite and organic acid, living cells are eliminated than at low concentrations of an agent. The antibacterial effects of sanitizers are thus not only dependent on the type of disinfectants and pathogens but also on their concentrations. Some bacteria are naturally unaffected by antimicrobial products and become resistant to antibiotics as a result of spontaneous changes in their DNA or gene transfer from by an unknown mechanism. It is thus important to select a disinfectant that is effective at removing specific types of microorganisms by suppressing the development and persistence of resistance.

Bases on the findings of this study, $\mathrm{CaO}$ and organic acids may be useful in reducing the presence of pathogens isolated from fresh cut product and organic vegetables. However, we suggest that using an organic acid to wash vegetable is a suitable method for the elimination of microorganisms. Organic acids can serve as an alternative to commercial disinfectants for the quality assurance of organic produce because these chemicals are inexpensive, safe, and offer high inhibitory effectiveness.

However, foodstuff can still create disinfectant-resistant microorganisms. Therefore, additional experiments are needed to investigate the development of antimicrobial resistance among pathogens in fresh produce to supply clear guidelines for the safe and effective use of disinfectants.

\section{요 약}

신선편의 샐러드와 유기농 채소에 오염되어 있는 식중독 균인 B. cereus, S. aureus 그리고 E. coli를 대상으로 살균 소독제와 유기산에 대한 감수성을 평가하여 신선편의 식품 의 미생물학적 안전성의 확보를 위한 올바른 세척제와 사 용량을 제시하고자 하였다.

S. aureus 는 2\% acetic acid, malic acid, tartaric acid와 $1 \% \mathrm{CaO}$ 에 대하여 고농도의 염소계, 과산화수소계 보다 높은 살균 효과를 보였고 E. coli의 경우에는 $1 \%$ acetic acid 와 $\mathrm{CaO}$ 처리에 의해 $80 \%$ 의 분리주가 감소하여 $50 \%$
에탄올과 $400 \mathrm{ppm}$ 차아염소산나트륨과 대등한 감소율을 보였다. B. cereus 분리주에 대한 $1 \% \mathrm{CaO}, 0.5 \%$ acetic acid, $2 \%$ malic acid와 tartaric acid 처리는 $200 \mathrm{ppm}$ 의 차 아염소산나트륨보다 높은 감소율을 나타내었고, $1 \%$ 의 과 산화수소와 대등한 감소율을 나타내었다. 본 연구에 따라 천연 물질 유래 살균 소독제인 $\mathrm{CaO}$ 와 유기산은 기존의 화 학적 살균제를 대체할 수 있는 천연 살균 소독제로 활용 될 수 있을 것이고 특히 환경 친화적이고 안전한 유기산은 고품질의 신선편의 채소를 안전성으로 공급하는데 효과적 인 것으로 판단되었다.

\section{Acknowledgments}

This study was supported by the Korea Food Research Institute, Republic of Korea.

\section{References}

1. Niemira BA, Fan X, Sokorai KJB.:Irradiation and modified atmosphere packaging of endive influences survival and regrowth of Listeria monocytogenes and product sensory qualities. Int. J. Radiat. Phys. Chem., 72, $41-48$ (2005).

2. McMahon, M. A. S. Wilson, I. G.:The occurrence of enteric pathogens and Aeromonas species in organic vegetables. Int. J. Food Microbiol., 70, 155-162 (2001).

3. Bhagwat, A. A.: Rapid detection of Salmonella from vegetable rinse-water using real-time PCR. Food Microbiol., 21, 73-78 (2004).

4. Korean Food and Drug Administration. http://e-stat.kfda.go. kr. Seoul, Korea. (2010).

5. Lazarova V, Janex M, Fiksdal L, Oberg C, Barcina I, Pommepuy M.: Advanced wastewater disinfection technologies: short and long term efficiency. Water Sci. Technol., 38, 109117(1998).

6. Park SH, Choi MR, Park JW, Park KH, Chung MS, RYU SR, Kang DH.: Use of Organic Acids to Inactivate Escherichia coli O157:H7, Salmonella Typhimurium, and Listeria monocytogenes on Organic Fresh Apples and Lettuce. J. Food Sci., 76, 6 (2011).

7. Akbas MY, Ölmez H.: Inactivation of Escherichia coli and Listeria monocytogenes on iceberg lettuce by dip wash treatments with organic acids. Lett. Appl. Microbiol., 44, 619-624 (2007).

8. Park HK, Kim SB.: Microbial reduction of fresh vegetables by treatment of sanitizing regents. Korean J. Food \& Nutr., 17, 436-441 (2004).

9. Jeong JW, Kim TK, Park JW, Lee KG.: Antimicrobial activity of sterilizer for the exclusive of vegetable against Escherichia coli and Staphylococcus aureus. Food Engin. Progr., 10, 221-225 (2006).

10. Kim IJ, Kim YS, Ha SD.: Bacteriocidal effect of $\mathrm{CaO}$ (Scallop-shell powder) on natural microflora and pathogenic bacteria in lettuce. J. Fd. Hyg. Safety., 21, 60-64 (2006). 
11. Ase B, Sundheim G, Langsrud S, Rorvik L.: Occurrence and a possible mechanism for resistance to a quaternary ammonium compound in Listeria monocytogenes. Int. J. Food Microbio., 62, 57-63 (2000).

12. Zhang S, Farber JM.: The effects of various disinfectants against Listeria monocytogenes on fresh-cut vegetables. Food Microbiol., 13, 311-21 (1996).

13. MS, Jeong A, Kim HJ, Lee N, Oh S, Kim Y, Chun HS, Koo M.: Microbiological quality of fresh-cut produce and organic vegetables. Kor. J. Food Sci. Technol., 43, 91-97 (2001).

14. CLSI. Performance standards for Antimicrobial Disk Susceptibility Tests. 10th ed. CLSI document M02-A10. Clinical and Laboratory Standards Institute, Wayne, Pennsylvania, USA (2009).

15. Knight, D. and Cooke, M. 2002. The Biocide Business: Regulations, Safety and Applications. Wiley-VCH, Germany.

16. Ingram LO.: Mechanism of lysis of Escherchia coli by ethanol and other chaotpic agents. J. Bacteriol., 146, 331-336 (1981).

17. Juven, B.J., M.D. Pierson.: Antibacterial effects of hydrogen peroxide and methods for its detection and quantitation. $J$. Food Prot., 59(11), 1233-1241 (1996).

18. Korean Food and Drug Administration. 2010. Korea Food Additives Code. Seoul, Korea.

19. Park HK, Kim SB. 2004. Microbial reduction of fresh vegetables by treatment of sanitizing regents. Korean J Food \& Nutr 17: 436-441.

20. Beuchat LR, Nail BV, Adler BB, Clavero MRS.: Efficacy of spray application of chlorinated water in killing pathogenic bacteria on raw apples, tomatoes and lettuce. J. Food Prot., 61, 1305-1311 (1998).

21. Eifert JD, Sanglay GC.: Chemistry of chlorine sanitizers in food processing. Dairy Food Environ. Sanit., 22, 534-538 (2002).

22. Bloomfield S.: Chlorine and iodine formulations. In Handbook of disinfectants and antiseptics. Joesph A. ed. Marcel Dekker. Inc. New York. 135-158 (1996).

23. Lee YS, Jo SH, Cho SD, Kim GH, Kim YM, Lee DH, Park SH, Bae DH, Chung MS, Bahk GJ, Ha SD.: Effects of Chlorine Concentrations and Washing Conditions on the Reduction of Microbiological Contamination in Lettuce. J. Korean Soc. Appl. Biol. Chem., 52(3), 270-274 (2009).

24. Sawai J, Miyoshi H, Kojima H.: Sporicidal kinetic of Bacillus subtilis spore by heated scallop shell powder. J. Food Prot., 66, 1482-1485 (2003).

25. Droby S, Wisniewski ME, Cohen L, Weiss B, Touitou D, Eilam Y and Chalutz E.: Influence of $\mathrm{CaCl}_{2}$ on Penicillium digitatum, Grapefruit Peel Tissue, and Biocontrol Activity of Pichia guilliermondii. Phytopathol., 87(3), 310 -315 (1997).

26. Langsrud, S., Sidhu, M.S., Heir, E., Holck, A.L.: Bacterial disinfectant resistance: a challenge for the food industry. Int. Biodeterioration \& Biodegradation., 51, 283-290 (2003).

27. Heir E, Sundheim G, Holock AL.: The qacG gene on plasmid pST94 confers resistance to quaternary ammonium compounds in staphylococci from the food industry. J. Applied of Bacteriol., 86, 378-388 (1999).

28. Russell AD.: Bacterial resistance to disinfectants: present knowledge and future problems. J. Hosp. Infect., 43, 57-68 (1998).

29. Minor TE, Marth EH.: Growth of staphylococcus aureus in acidified pasteurized milk. J. Milk Food Technol., 33, 516520 (1970).

30. Jo, S.C., A.R. Rim, H.J. Park, H.G. Yuk, S.C. Lee.: Combined treatment with silver ions and organic acid enhances growth-inhibition of Escherichia coli O157: H7. J. Food Control., 18, 1235-1240 (2006).

31. Souza, E.L., Barros, J.C., da Conceição, M.L., Gomes Neto, N.J., Costa, A.C.V.: Effect of Organic Acids on Escherichia coli O157:H7 and Staphylococcus aureus Contaminated Meat. The Open Microbiol. J., 3, 121-127 (2009).

32. de Souza, E. L., de Barros, J. C., da Conceição, M. L., Gomes Neto, N. J., Da Costa, A. C. V.: Combined applications of Origanum vulgare L. essential oil and acetic acid for controlling the growth of Staphylococcus aureus in foods. Braz. J. Microbiol., 40, 387-393 (2009).

33. Hsiao, C. P., Siebert, K. J.: Modeling the inhibitory effects of organic acids on bacteria. Int. J. Food Microbiol., 47, 189-201 (1999).

34. Conner DE, Scott VN, Bernard DT.: Growth, inhibition and survival of Listeria monocytogenes as affected by acidic conditions. J. Food Prot., 53, 652-655 (1990).

35. Ahn YS, Shin DH.: Antimicrobial effects of organic acids and ethanol on several foodborne microorganisms. Korean J. Food Sci Technol., 31, 1315-1323 (1999).

36. Russell AD.: Bacterial spores and chemical sporicidal agents. Clin Microbiol Rev., 3(2), 99-119 (1990).

37. Hoxey, E. V. and Thomas, N. (1999), Gaseous sterilization, in Russell, A. D., Hugo, W. B.and Ayliffe, G. A. J. Principles and Practice of Disinfection, Preservation and Sterilization, Blackwell Science Ltd, Oxford.

38. Francis G.A., Thomas C, O., Beirne D.: The microbiological safety of minimally processed vegetables, Int J Food Sci Technol.; 34, 1-22 (1999). 